\title{
The Freshman 15: A Critical Time for Obesity Intervention or Media Myth?*
}

\author{
Jay L. Zagorsky, The Ohio State University \\ Patricia K. Smith, University of Michigan-Dearborn
}

Objectives. We test whether the phrase "Freshman 15" accurately describes weight change among first-year college students. We also analyze freshmen's weight change during and after college. Methods. This is the first investigation of the "Freshman 15" to use a nationally representative random sample, the National Longitudinal Survey of Youth (NLSY97). The data are analyzed using descriptive statistics, regression analysis, simulations, and longitudinal analysis. Results. Freshmen gain between 2.5 to 3.5 pounds, on average, over the course of their first year of college. Compared to sameage noncollege attendees, the typical freshman gains only an additional half-pound. Instead of a spike in weight during the freshman year, college-educated individuals exhibit moderate but steady weight gain during and after college. Conclusion. Antiobesity efforts directed specifically at college freshmen will likely have little impact on obesity prevalence among young adults.

Many college-bound students worry about the "Freshman 15," the much publicized notion that students tend to gain substantial weight during their first year at college. This fear is partly based on the upward trend in the average adult's weight. Since the early 1970s, the U.S. adult obesity rate has risen from about 14 percent of the population to nearly 35 percent (National Center for Health Statistics, 2009). Stemming and reversing the obesity trend is important because it could reduce public and private health-care costs and improve labor productivity (Klarenbach et al., 2006; Thorpe, 2005; Tunceli, $\mathrm{Li}$, and Williams, 2006; Wee et al., 2005). One obesity prevention strategy is to identify points in the lifecourse when weight gain is a particular risk and to focus interventions on these critical periods. Since college freshmen experience increased freedom over their diets, alcohol consumption, and sleep patterns, this transitional year may be such a critical period (Baranowski et al., 1997; Compas et al., 1986).

If the "Freshman 15 " is a real phenomenon, then the first year of college would be a time to focus efforts to encourage healthy lifestyle habits in order to prevent obesity. If, however, the "Freshman 15 " is a media myth, then

\footnotetext{
*Direct correspondence to Patricia K. Smith, Department of Social Sciences, University of Michigan-Dearborn, 4901 Evergreen Rd., Dearborn, MI 48128 〈pksmith@umich.edu〉. All data and coding materials are available from the second named author at the mailing address above.
} 
focusing anti-obesity efforts on new college students will prove ineffective and repeated warnings about weight gain may cause unnecessary worry or worsen body image in ways that actually contribute to weight gain.

This article offers the first examination of the "Freshman 15" based on a large nationally representative random sample of college freshmen. In addition, this analysis compares freshmen to similarly aged noncollege students. The results indicate that the "Freshman 15 " is generally a myth: students gain only about three pounds on average during their first year in college. Furthermore, compared to noncollege attendees of the same age, the typical college freshman only gains an additional half-pound of weight. Longitudinal analysis of weight change before, during, and after college shows steady weight gain in all three time periods, not just during college.

\section{Literature Review}

Hovell et al. (1985) introduced the notion of significant weight gain during the freshman year of college based on a small sample of women at a private university. They found that the average female student gained eight to nine pounds during the first year of college. The first article to use the term "Freshman 15" appeared in 1989 in Seventeen Magazine, a publication targeting young women (Watkins, 1989). During the 1980s, only a handful of "Freshman 15" articles appeared each year, but beginning in the late 1990s the number of such publications increased significantly (Brown, 2008). These articles generally used the concept to motivate advice on how to avoid gaining weight and about half of them did not refute or question the reality of the "Freshman 15."

Since Hovell and colleagues' initial paper, 19 academic studies using longitudinal analyses of weight change among college freshmen have been published (Table 1). While the early analyses focused on women, about half the extant studies include men. Among those studies examining freshmen of both genders, all but one included more women than men in their samples. Overall, this literature indicates that freshmen typically do gain weight, but not nearly 15 pounds. The observed average weight change runs from a minimum of -1.5 to a maximum of 8.8 pounds, with a mean of 3.8 pounds. The two studies that examined weight change by gender both report that freshmen women gained half a pound more than their male counterparts. However, all these studies used small single-campus samples and many were nonrandom, limiting the generalizability of the results.

\section{Theory}

Researchers offer six basic theories for why freshmen might gain weight. First, students may switch from eating more nutritious home-cooked foods 


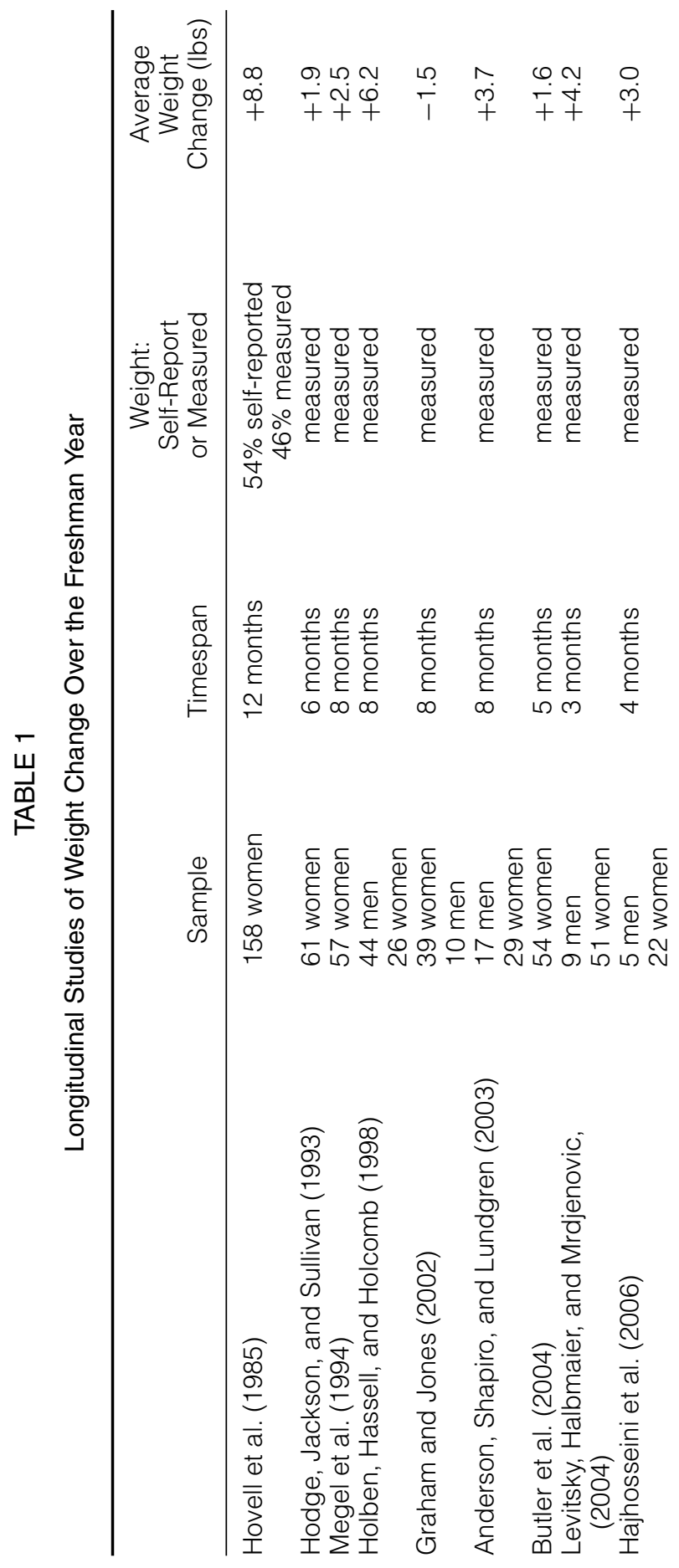




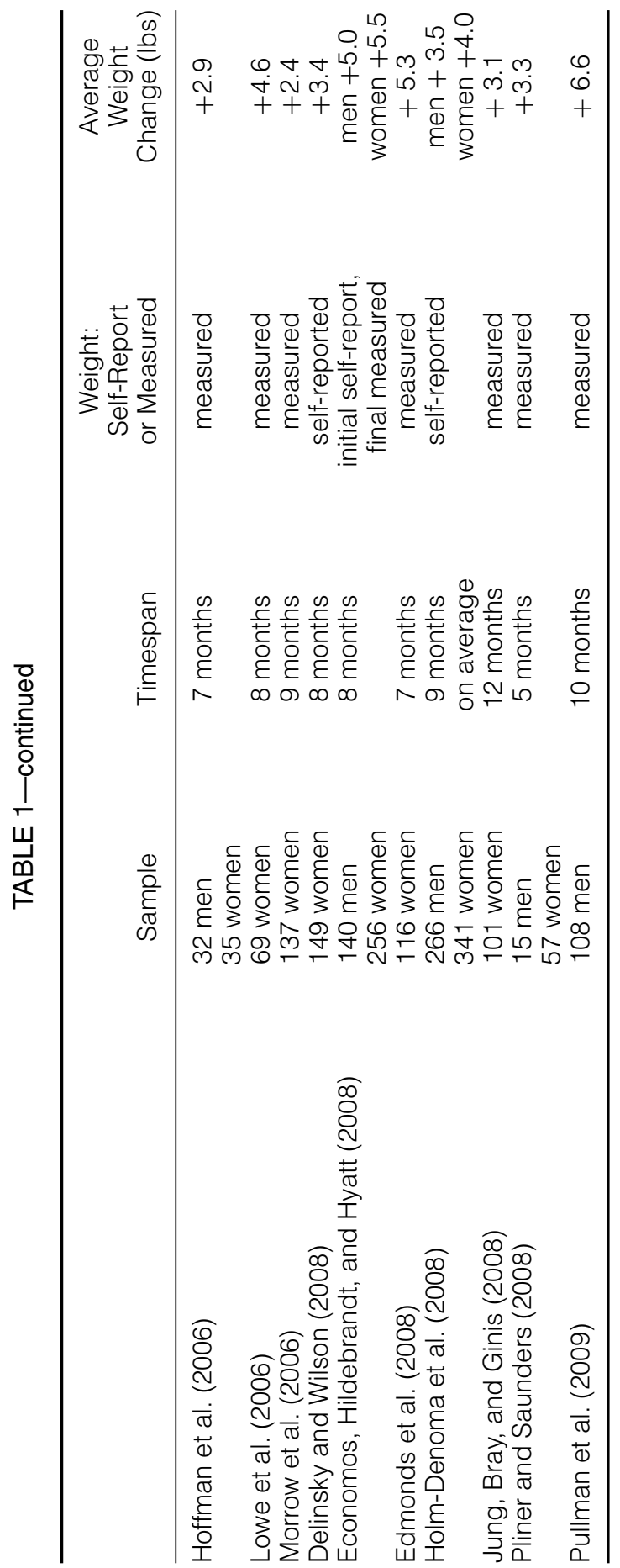


to caloric-dense institutional food (Pliner and Saunders, 2008). Second, the lack of parental oversight means students are more likely to eat an unbalanced diet. Although young adults not attending college who leave their parental home may experience these same two phenomena, there is concern that college campuses with all-you-can-eat cafeterias and snack foods readily available in dorms may make this environment especially obesogenic (Baranowski et al., 1997; Pliner and Saunders, 2008; Nelson et al., 2009). Third, college expenses may strain budgets, potentially causing students to shift to cheaper, higher-calorie foods (Drewnowski, 2004). Findings of the National College Health Assessment are consistent with these theories: only 5 percent of college students reported consuming the recommended amount of fruits and vegetables (American College Health Association, 2009). However, in samples of individuals in their late teens, not just college students, researchers have also observed declines in fruit and vegetable consumption (Demory-Luce et al., 2004; Larson et al., 2007).

Increased stress caused by the transition from high school to college is a fourth possible route to weight gain because chronic stress is associated with biochemical changes that foster weight gain (Björntorp, 2001; Drapeau et al., 2003). Furthermore, students may cope with the additional stress by eating high-calorie comfort foods (Dallman et al., 2003; Kandiah et al., 2006; Wansink, Cheney, and Chan, 2003) and increasing alcohol consumption (Wechsler and Nelson, 2008), especially those living on campus (Gfroerer, Greenblatt, and Wright, 1997). Since most alcoholic drinks are calorie-dense, this could lead to a substantial rise in calorie intake.

Freshmen may also gain weight because college students sleep less due to increased study time (Carskadon, 1990; Hicks, Fernandez, and Pellegrini, 2001), which can increase appetite and the preference for carbohydrates (Hasler et al., 2004; Pullman et al., 2009; Spiegel et al., 2004). The National College Health Assessment reports that only 10 percent of college students get "enough sleep to feel rested in the morning" at least six days a week, while 48 percent get enough sleep three to five days weekly (American College Health Association, 2009). Furthermore, students may use calorie-intensive caffeinated drinks to help stay awake (Malinauskas et al., 2007; Shields, Corrales, and MetallionosKatsaras, 2004). The rise in the number of university libraries that offer coffee shops may encourage this practice (Horovitz, 2007).

Finally, students' level of physical activity may decrease from high school to college since physical education requirements and participation in team sports generally decline while study time increases. Observed trends in physical activity are consistent with this hypothesis (Gordon-Larson, Nelson, and Popkin, 2004; Nelson et al., 2006). Notably, the Surgeon General found that during the 1990s, the largest declines in physical activity took place during late adolescence (U.S. Department of Health and Human Services, 1996). Although the reduction in physical activity among young adults holds for both college students and nonstudents, studying may require students to spend more time in sedentary pursuits. The National College Health Assessment 
found that only 19 percent of college students reported meeting the recommended amount of moderate-intensity physical activity (American College Health Association, 2009).

\section{Methodology}

This research investigates freshman weight gain using data from the National Longitudinal Survey of Youth 1997 cohort (NLSY97) by employing descriptive statistics, linear regressions, simulations, and longitudinal analysis. The NLSY97 is a nationally representative panel survey of nearly 9,000 people living in the United States in 1997 and born between 1980 and 1984. As of 2011, the NLSY97 has interviewed the same people annually 14 times and publicly released 12 rounds of data. All data used in this research are available online at $\langle$ www.bls.gov/nls/nlsy97.htm $\rangle$.

The NLSY97 panel consists of two groups: a nationally representative sample of 6,748 youths and a supplemental oversample of 2,236 black and Hispanic youth. Since results are more precise using both groups, they are combined using the methods outlined in the NLSY97 User Guide. ${ }^{1}$ All descriptive tables and graphs use data adjusted for the sampling structure using the 1997 baseline weight (variable R12361.01). This weighting ensures that the characteristics of the oversampled respondents do not unduly influence the results. Regressions do not use weighted data; instead, they are adjusted by explicitly adding control variables that account for oversampled respondents.

Table 2 provides a demographic overview of the respondents using information from the 2007 interview, which were the latest data available when this research was conducted. Column (1) shows that during 2007, respondents ranged in age from 22 to 28 , with the typical respondent being nearly 25 years old, and were about evenly divided between men and women. Seventy percent of the cohort is white, 16 percent is black, and almost 13 percent is Hispanic. The majority (89.3 percent) have graduated from high school or obtained a GED and more than 60 percent have started college. About one-third have married and about one in 20 ( 4.5 percent) have divorced. The typical respondent worked 39.2 weeks in the past year and nearly 17 percent lived in poverty. Median family income, measured as the sum of all incomes earned by people over age 14 who resided with the respondent, is slightly more than $\$ 45,000$. Finally, a substantial number (37 percent) live in the southern U.S. Census region.

Columns (2) and (3) of Table 2 disaggregate the demographic and socioeconomic data by gender. Although the demographic characteristics do not differ much by gender, most of the socioeconomic characteristics do. Women in the sample have more education, a higher chance of being married, and a higher chance of being divorced. Women are also more likely to be poor and

\footnotetext{
${ }^{1}$ See 〈http://www.nlsinfo.org/nlsy97/nlsdocs/nlsy97/use97data/weights.html .
} 
TABLE 2

Demographic and Socioeconomic Characteristics of NLSY97 Respondents in 2007

\begin{tabular}{|c|c|c|c|c|c|}
\hline Category & $\begin{array}{l}\text { All } \\
(1)\end{array}$ & $\begin{array}{l}\text { Males } \\
(2)\end{array}$ & $\begin{array}{c}\text { Females } \\
\text { (3) }\end{array}$ & $\begin{array}{c}\text { Never } \\
\text { Attended } \\
\text { College } \\
(4)\end{array}$ & $\begin{array}{c}\text { Attended } \\
\text { College } \\
\text { (5) }\end{array}$ \\
\hline \multicolumn{6}{|l|}{ Demographic } \\
\hline Youngest age & 22 years & 22 years & 22 years & 22 years & 22 years \\
\hline Oldest age & 28 years & 28 years & 28 years & 28 years & 28 years \\
\hline Average age & 24.9 years & 24.9 years & 24.9 years & 24.9 years & 24.9 years \\
\hline $\begin{array}{l}\text { Percent } \\
\text { female** }\end{array}$ & $49.2 \%$ & $0 \%$ & $100 \%$ & $42.2 \%$ & $53.4 \%$ \\
\hline Percent white & $70.0 \%$ & $70.1 \%$ & $69.8 \%$ & $63.0 \%$ & $74.1 \%$ \\
\hline Percent black & $16.0 \%$ & $15.4 \%$ & $16.6 \%$ & $20.1 \%$ & $13.5 \%$ \\
\hline $\begin{array}{l}\text { Percent } \\
\text { Hispanic }\end{array}$ & $12.9 \%$ & $13.3 \%$ & $12.4 \%$ & $15.7 \%$ & $11.1 \%$ \\
\hline \multicolumn{6}{|l|}{ Socioeconomic } \\
\hline $\begin{array}{l}\text { High school } \\
\text { graduate }^{* *}\end{array}$ & $89.3 \%$ & $88.4 \%$ & $90.2 \%$ & $72.9 \%$ & $99.1 \%$ \\
\hline $\begin{array}{l}\text { Started } \\
\text { college }\end{array}$ & $62.5 \%$ & $57.4 \%$ & $67.9 \%$ & $0 \%$ & $100 \%$ \\
\hline Ever married** & $30.0 \%$ & $24.7 \%$ & $35.5 \%$ & $31.7 \%$ & $29.0 \%$ \\
\hline Ever divorced** & $4.5 \%$ & $3.6 \%$ & $5.3 \%$ & $6.4 \%$ & $3.3 \%$ \\
\hline $\begin{array}{l}\text { Live in } \\
\text { poverty** }\end{array}$ & $16.7 \%$ & $15.6 \%$ & $17.9 \%$ & $23.6 \%$ & $12.8 \%$ \\
\hline Live in South & $37.0 \%$ & $36.1 \%$ & $38.0 \%$ & $41.0 \%$ & $34.6 \%$ \\
\hline $\begin{array}{l}\text { Weeks work in } \\
\text { past year** }\end{array}$ & 39.2 & 39.7 & 38.7 & 35.9 & 41.2 \\
\hline $\begin{array}{l}\text { Median family } \\
\text { income** }\end{array}$ & $\$ 45,015$ & $\$ 45,000$ & $\$ 45,525$ & $\$ 37,500$ & $\$ 51,265$ \\
\hline$N$ & 7,418 & 3,735 & 3,683 & 3,009 & 4,409 \\
\hline
\end{tabular}

Notes: ${ }^{* *}$ in the category column indicates that the gender differences are statistically significant at the 5 percent level. Data are for all respondents who completed the 2007 interview and are weighted using R12361.01. Age is the respondent's age on the day of the interview. Age, race, and gender are based on the NLSY97 variables T00085.00, R14826.00, and R05363.00, respectively. High school graduate is based on T00146.00. Started college is based on checking the monthly college enrollment status array, which starts at variable R95970.00, and checking if the respondent ever enrolled. Marital status indicators are based on T00255.00. Geographic data are based on T00094.00. The start and stop dates of every job reported by the respondent are tracked in the NLSY97. Using this job history information, the authors created "weeks worked in the past year." Median family income is taken from T00141.00.

live in the South and report fewer hours worked, but somewhat higher family income. Columns (4) and (5) break the sample down by college attendance. College attendees are more likely to be white, female, and have a dramatically higher family income than those who do not attend college.

A key module of the NLSY97 tracks the respondent's college experience. This module not only asks about the specific start and stop dates of 
respondents' college attendance, but also gathers information on where they attended, funding, and living arrangements. This analysis uses the respondents' month-by-month college enrollment status, ${ }^{2}$ which shows the particular months a respondent attended college starting in January 1997. Because 83 (about 1 percent) of the survey's high school students took some college courses before finishing their $\mathrm{K}-12$ education, we exclude from the analysis all college enrollments that occurred before a respondent obtained a high school diploma or GED.

The majority of NLSY97 respondents started college at age 18 (58.2 percent). Significantly fewer people started at age 17 (7.8 percent) and almost no one started college before 17 ( 0.4 percent). About one-fifth (18.4 percent) started at age 19 and the rest (15.2 percent) started at age 20 or older. Thus, this analysis primarily tracks the experiences of 17 to 19 year olds.

Each wave of the NLSY97 asks respondents to report their weight. Response rates to weight questions are high, with the greatest nonresponse (3 percent) occurring in 1997. Response rates improved slightly over time, with just 2.3 percent of respondents not answering the question by 2007. In addition to nonresponse, 60 observations were eliminated because the respondent reported weighing less than 26 pounds. ${ }^{3}$

Sherry, Jefferds, and Grummer-Strawn find that youth's self-reported weight figures contain errors and biases; girls tend to underestimate their weight compared to boys and overweight youth underestimate their weight more than those of normal weight. However, they note that there is a "lack of information on whether biases are consistent over time" (2007:1159). If people are consistent in their biases from year to year, this kind of measurement error will not impact analytical results. If, however, respondents' self-reporting biases vary over time, result quality will be diminished.

Since the specific self-reporting bias for college students has not been researched, we analyzed data from the National Health and Nutrition Examination Survey (NHANES) 2007-2008, following Rowland (1990). ${ }^{4}$ The NHANES contains self-reported and clinically measured weight. Comparing these two variables for people aged 17 to 22 reporting a college education shows the average college male underestimates his weight by half a pound or less (mean 0.5 pounds; median 0.2 ). The average college female underestimates her weight by two to three pounds (mean 3.3 pounds; median 1.8).

Rowland (1990) provides a regression framework to adjust for bias in selfreported weight. Applying this framework to the 2007-2008 NHANES data for college students shows that males' self-reported weights need to be inflated by roughly 3 percent and females' by 4 percent. Rerunning the descriptive and regressions analyses in this research using these adjustments produces almost

\footnotetext{
${ }^{2}$ Enrollment status items start with variable R95970.00.

${ }^{3}$ The removal of college women who were pregnant during their freshman year had no qualitative or quantitative impact on the findings. They were left in the final sample to ease replication of the results.

${ }^{4}$ See $\langle$ http://www.cdc.gov/nchs/nhanes.htm $\rangle$.
} 
the same results, which matches the findings in Zagorsky and Smith (2009). Since the adjusted and unadjusted analyses are so similar, only unadjusted figures are reported to ease replication.

The weight information from all the surveys was transformed into a monthby-month series using a cubic-spline interpolation if possible and a linear interpolation otherwise. An appendix is available upon request that contains a full description of the interpolation methods and shows that the interpolated and noninterpolated results produce the same conclusions.

\section{Results}

Four types of results are presented. First, a set of descriptive results tracks mean and median weight changes. Second, multivariate regressions are run that adjust each individual's weight gain for specific factors such as age, gender, race, and college experience. Third, simulations estimate the difference in weight gain between young adults attending and not attending college. Lastly, a longitudinal analysis examines weight change during and after college.

\section{Descriptive Results}

Freshmen women gained slightly more than three pounds and men gained three and a half pounds, on average (Columns (1) and (2) in Table 3). Median weight gain falls slightly below the mean, with females gaining 2.4 pounds and males gaining 3.4. No more than 10 percent of college freshmen gained 15 pounds, so the vast majority did not experience the "Freshman 15." Moreover, 25 percent of college freshmen reported losing weight during their first year. These results suggest that the "Freshman 15 " is largely a myth.

Columns (3) and (4) of Table 3 report total weight gain during all years of college for students who graduated. These columns indicate that the average student does not gain 15 pounds over the course of his or her entire university career. Instead, the typical female gained between seven to nine pounds (median 6.5 pounds; mean 8.9 pounds), while the typical male gained between 12 and 13 pounds from start to finish (median 12.1 pounds; mean 13.4 pounds). Although students did not gain much weight their freshman year, they did accumulate more over their college careers. Even so, the typical student gained less than 15 pounds while in college.

Since the college experience is not homogenous, Table 4 shows how freshman weight gain varies across five factors: full-time versus part-time status; two-year versus four-year degree; private versus public institution; lived in a dormitory or elsewhere; and heavy drinking status (consuming six or more drinks on at least four days per month). Women attending college full time gained an average of 3 pounds during their first year versus a 3.7 pound weight gain for females going part-time, although this difference is not statistically 
TABLE 3

Weight Gain in College by Gender

\begin{tabular}{lcccc}
\hline & $\begin{array}{c}\text { Female } \\
\text { Freshman } \\
\text { Year } \\
(1)\end{array}$ & $\begin{array}{c}\text { Male } \\
\text { Freshman } \\
\text { Year } \\
(2)\end{array}$ & $\begin{array}{c}\text { Female } \\
\text { Total College } \\
\text { Career } \\
(3)\end{array}$ & $\begin{array}{c}\text { Male } \\
\text { Total College } \\
\text { Career } \\
(4)\end{array}$ \\
\hline Top 1\% & $36.2 \mathrm{lbs}$ & $30.0 \mathrm{lbs}$ & $57.0 \mathrm{lbs}$ & $63.9 \mathrm{lbs}$ \\
Top 5\% & $18.2 \mathrm{lbs}$ & $19.5 \mathrm{lbs}$ & $40.4 \mathrm{lbs}$ & $41.7 \mathrm{lbs}$ \\
Top 10\% & $12.8 \mathrm{lbs}$ & $14.7 \mathrm{lbs}$ & $28.6 \mathrm{lbs}$ & $34.5 \mathrm{lbs}$ \\
Top 25\% & $6.8 \mathrm{lbs}$ & $8.7 \mathrm{lbs}$ & $15.7 \mathrm{lbs}$ & $22.1 \mathrm{lbs}$ \\
Median & $2.4 \mathrm{lbs}$ & $3.4 \mathrm{lbs}$ & $6.5 \mathrm{lbs}$ & $12.1 \mathrm{lbs}$ \\
Bottom 25\% & $-1.1 \mathrm{lbs}$ & $-1.3 \mathrm{lbs}$ & $0 \mathrm{lbs}$ & $4.2 \mathrm{lbs}$ \\
Bottom 10\% & $-6.0 \mathrm{lbs}$ & $-7.0 \mathrm{lbs}$ & $-6.8 \mathrm{lbs}$ & $-3.6 \mathrm{lbs}$ \\
Bottom 5\% & $-9.6 \mathrm{lbs}$ & $-11.0 \mathrm{lbs}$ & $-12.8 \mathrm{lbs}$ & $-10.9 \mathrm{lbs}$ \\
Bottom 1\% & $-20.9 \mathrm{lbs}$ & $-25.8 \mathrm{lbs}$ & $-25.8 \mathrm{lbs}$ & $-35.8 \mathrm{lbs}$ \\
Mean & $3.1 \mathrm{lbs}$ & $3.5 \mathrm{lbs}$ & $8.9 \mathrm{lbs} * * *$ & $13.4 \mathrm{lbs} * *$ \\
SD & $10.1 \mathrm{lbs}$ & $10.3 \mathrm{lbs}$ & $16.4 \mathrm{lbs}$ & $18.5 \mathrm{lbs}$ \\
$N$ & 2,536 & 2,151 & 1,134 & 837 \\
\hline
\end{tabular}

NOTE: ${ }^{* * *}$ means the gender figures are statistically distinct at the 1 percent level.

TABLE 4

College Freshman Year Mean Weight Gain in Pounds by Key Characteristics

\begin{tabular}{lcrrcrrr}
\hline & $\begin{array}{c}\text { Female } \\
\text { Weight Gain }\end{array}$ & $S D$ & $N$ & Weight Gain & $S D$ & $N$ \\
\hline Full time & 3.0 & $(10.0)$ & 2,142 & 3.4 & $(10.0)$ & 1,678 \\
Part time & 3.7 & $(10.6)$ & 394 & 4.2 & $(11.9)$ & 322 \\
Private college & 2.9 & $(9.1)$ & 511 & 3.6 & $(9.4)$ & 397 \\
Public college & 3.2 & $(10.3)$ & 2,025 & 3.5 & $(10.5)$ & 1,754 \\
4-year degree & $2.8^{* *}$ & $(8.6)$ & 1,483 & 3.5 & $(9.5)$ & 1,261 \\
2-year degree & $3.6^{* *}$ & $(12.1)$ & 1,053 & 3.5 & $(11.4)$ & 890 \\
Never live in dorm & $3.5^{* *}$ & $(11.5)$ & 1,441 & $3.0^{* *}$ & $(11.7)$ & 1,214 \\
Ever live in dorm & $2.7^{* *}$ & $(8.1)$ & 1,095 & $4.1^{* *}$ & $(8.3)$ & 937 \\
Not heavy drinker & 3.1 & $(10.2)$ & 2,119 & 3.2 & $(10.8)$ & 1,524 \\
Heavy drinker & 3.2 & $(9.7)$ & 417 & 4.1 & $(8.9)$ & 627 \\
\hline
\end{tabular}

NOTE: ${ }^{* *}$ means the pair of figures is statistically distinct at the 5 percent level.

significant. For freshmen women, two factors exhibit statistically significant differences in weight gain. First, those at two-year institutions gained almost a pound more than their counterparts at four-year institutions (3.6 vs. 2.8 pounds). Second, freshmen women who ever lived in a dorm gained about 1 pound less than those who never lived in a dorm ( 2.7 vs. 3.5 pounds). This latter result contradicts the hypothesis that the dorm environment is particularly obesogenic. 
The two largest differences in Table 4 concern men living in a dorm compared to those living in a noncampus setting and male heavy drinkers versus nonheavy drinkers. Although the difference between drinking categories (4.1 vs. 3.2 pounds) is not statistically significant at the 5 percent level, it is significant at the 10 percent level. Freshmen men who ever lived in a dorm gained 4.1 pounds, on average, while men who never lived in a dorm gained 3 pounds, a statistically significant difference at the 5 percent level. In contrast to the result for women, these findings support the hypothesis that the dorm environment and heavy drinking encourage weight gain among freshmen men.

\section{Multivariate Linear Regression Results}

We next conduct regression analysis of weight gain using the characteristics presented in Table 4 and additional demographic factors such as age, gender, and race/ethnicity. Table 5 presents the ordinary least squares (OLS) estimates of the association between each characteristic and weight change for individuals who ever reported attending college, while controlling for the other factors.

Regression (1) of Table 5 focuses on the freshman year. Except for the coefficients on heavy drinkers and Hispanics, the estimated coefficients are not statistically distinguishable from zero. In particular, the regression results do not support the hypothesis that the dorm environment encourages weight gain during the freshman year. Even though the heavy drinker coefficient is marginally statistically significant, its magnitude suggests a relatively small effect, a weight increase less than one pound.

Regression (2) of Table 5 also examines freshman-year weight gain and includes the additional socioeconomic factors found at the bottom of Table 2 , such as marital status, income, and poverty. Instead of using just the 2007 data, these extra factors correspond to what happened to respondents during their freshman year. None have statistically significant coefficients, suggesting that none of the socioeconomic factors help explain weight change over the freshman year.

Regressions (3) and (4) of Table 5 show each characteristic's association with the weight change from the start to end of college for graduates. The coefficients on YEARS IN COLLEGE indicate that respondents gain an average of three pounds per year after controlling for the other characteristics. The results again offer no support for the hypothesis that living in a dorm encourages weight gain. In contrast to the freshman-year results, heavy drinking no longer exhibits a statistically significant association with weight gain. This suggests that while alcohol consumption may contribute to some weight gain among freshmen, it is not associated with weight gain among students in general. Also, students attending two-year institutions gain about two pounds more than students in four-year institutions over their college careers and 
women tend to gain less weight than men, on average. ${ }^{5}$ The only statistically significant socioeconomic variable in Regression (4) is weeks worked; each additional week of work is associated with a nearly half-pound rise in weight.

\section{Simulations: Weight Gain of Freshmen Versus Young Adults Not Attending College}

While the typical student entering college gains about three pounds the first year, it is important to determine whether this increase results from the transition to college or if it is typical of people in this age group regardless of college attendance. Weight-for-age growth charts produced by the Centers for Disease Control and Prevention (CDC) show that median weight of males and females in general rises from ages 17 to 20 . Anthropologists report that males typically experience a spurt in muscle mass growth around age 17 (Bogin, 1999:216), which could account for the greater weight gain of freshman males relative to freshman females. Nelson et al. (2008) argue that ages 18 to 25 mark an important transitional period in human development, which they call "emerging adulthood," that may place individuals at risk of weight gain regardless of their college-attendance status.

Because most people start college at age 18 we first focus on respondents aged 18 to 19 years. The NLSY97 data show that between ages 18 and 19 , women who attended college gained 3.55 pounds (mean) while women who never attended gained 3.54 pounds, a statistically insignificant difference. Among males, the mean college attendee gained 5.53 pounds ( $S D$ 12.3) from ages 18 to 19 , while nonattendees gained 4.49 pounds ( $S D$ 14.8), a statistically significant difference at the 5 percent level. These results suggest that the college environment itself is not a contributor to weight gain among young women, but may contribute to some weight gain among young men.

Since over 40 percent of college attendees do not start college at age 18, a more accurate weight comparison was conducted using a simulation. In the simulation, each person who never attended college was randomly assigned the college starting age of an NLSY97 respondent who did. The nonattendee's weight gain from the randomly selected starting age to 12 months later was then calculated. This simulation was then run 10,000 times for each nonattendee. The results show females not attending college gained slightly more than two pounds over their simulated first year (2.00 median; 2.52 mean, $S D$ 8.4, 1,494 observations). Males who did not go to college gained about three pounds (2.94 median; 3.18 mean, SD 8.4, 2,151 observations) over their simulated first year. Comparing the simulated values with actual college

\footnotetext{
${ }^{5}$ Including data on the specific year a respondent started college did not change the results since the coefficients on this variable were not statistically significant in any regression.
} 
TABLE 5

Regression Results for College Students with Standard Errors

\begin{tabular}{|c|c|c|c|c|}
\hline & $\begin{array}{c}\text { Freshman- } \\
\text { Year } \\
\text { Weight } \\
\text { Change } \\
\text { (1) }\end{array}$ & $\begin{array}{c}\text { Freshman- } \\
\text { Year } \\
\text { Weight } \\
\text { Change } \\
(2)\end{array}$ & $\begin{array}{c}\text { Total } \\
\text { College } \\
\text { Weight } \\
\text { Change } \\
\text { (3) }\end{array}$ & $\begin{array}{c}\text { Total } \\
\text { College } \\
\text { Weight } \\
\text { Change } \\
\text { (4) }\end{array}$ \\
\hline Constant & $\begin{array}{l}6.2^{* * *} \\
(2.3)\end{array}$ & $\begin{array}{l}5.9^{* *} \\
(2.9)\end{array}$ & $\begin{array}{c}7.6 \\
(9.8)\end{array}$ & $\begin{array}{c}6.0 \\
(11.8)\end{array}$ \\
\hline Age & $\begin{array}{c}-0.2 \\
(0.1)\end{array}$ & $\begin{array}{l}-0.2 \\
(0.15)\end{array}$ & $\begin{array}{c}-0.4 \\
(0.5)\end{array}$ & $\begin{array}{c}-0.3 \\
(0.6)\end{array}$ \\
\hline Female & $\begin{array}{r}-0.2 \\
(0.3)\end{array}$ & $\begin{array}{c}-0.1 \\
(0.4)\end{array}$ & $\begin{array}{c}-4.3^{* * *} \\
(0.8)\end{array}$ & $\begin{array}{c}-4.6^{* * * *} \\
(0.9)\end{array}$ \\
\hline Black & $\begin{array}{c}0.6 \\
(0.4)\end{array}$ & $\begin{array}{c}0.4 \\
(0.5)\end{array}$ & $\begin{array}{c}-0.1 \\
(1.1)\end{array}$ & $\begin{array}{l}2.8^{*} \\
(1.4)\end{array}$ \\
\hline Hispanic & $\begin{array}{l}0.9^{* *} \\
(0.4)\end{array}$ & $\begin{array}{l}1.2^{* *} \\
(0.5)\end{array}$ & $\begin{array}{c}0.8 \\
(1.2)\end{array}$ & $\begin{array}{c}2.3 \\
(1.5)\end{array}$ \\
\hline Part time & $\begin{array}{c}0.4 \\
(0.5)\end{array}$ & $\begin{array}{c}0.5 \\
(0.6)\end{array}$ & $\begin{array}{c}2.4 \\
(1.6)\end{array}$ & $\begin{array}{c}1.9 \\
(2.1)\end{array}$ \\
\hline 2-year degree & $\begin{array}{c}0.6 \\
(0.4)\end{array}$ & $\begin{array}{c}0.9^{*} \\
(0.5)\end{array}$ & $\begin{array}{l}2.4^{* *} \\
(1.1)\end{array}$ & $\begin{array}{l}2.1 \\
(1.5)\end{array}$ \\
\hline Public college & $\begin{array}{c}-0.02 \\
(0.4)\end{array}$ & $\begin{array}{c}-0.12 \\
(0.5)\end{array}$ & $\begin{array}{c}0.01 \\
(0.9)\end{array}$ & $\begin{array}{c}-0.7 \\
(1.1)\end{array}$ \\
\hline Ever live in dorm & $\begin{array}{c}0.3 \\
(0.4)\end{array}$ & $\begin{array}{c}0.7 \\
(0.5)\end{array}$ & $\begin{array}{c}0.1 \\
(1.0)\end{array}$ & $\begin{array}{c}0.8 \\
(1.2)\end{array}$ \\
\hline Heavy drinker & $\begin{array}{c}0.7^{*} \\
(0.4)\end{array}$ & $\begin{array}{c}0.6 \\
(0.5)\end{array}$ & $\begin{array}{c}-1.0 \\
(1.0 .)\end{array}$ & $\begin{array}{c}-0.9 \\
(1.1)\end{array}$ \\
\hline Years in college & & & $\begin{array}{l}3.0^{* * * *} \\
(0.3)\end{array}$ & $\begin{array}{l}3.2^{* * *} \\
(0.4)\end{array}$ \\
\hline Currently married & & $\begin{array}{c}-0.3 \\
(1.0)\end{array}$ & & $\begin{array}{c}4.9 \\
(3.8)\end{array}$ \\
\hline Living in poverty & & $\begin{array}{c}-0.3 \\
(0.6)\end{array}$ & & $\begin{array}{c}-1.7 \\
(1.5)\end{array}$ \\
\hline Living in South & & $\begin{array}{c}0.2 \\
(0.4)\end{array}$ & & $\begin{array}{c}-1.5 \\
(1.0)\end{array}$ \\
\hline $\begin{array}{l}\text { Weeks worked } \\
\text { past year }\end{array}$ & & $\begin{array}{l}0.002 \\
(0.01)\end{array}$ & & $\begin{array}{l}0.045^{*} \\
(0.03)\end{array}$ \\
\hline Family income & & $\begin{array}{c}-0.003 \\
(0.003)\end{array}$ & & $\begin{array}{c}-0.01 \\
(0.01)\end{array}$ \\
\hline N & 4,687 & 3,236 & 1,971 & 1,431 \\
\hline
\end{tabular}

NOTE: *, **, and *** means statistically distinct at the 10 percent, 5 percent, and 1 percent level, respectively. The number of respondents is lower in Columns (2) and (4) because not all NLSY97 respondents reported their income. Income is measured in \$1,000 increments.

attendees' weight change (Table 3) shows the average person going to college gains an extra half-pound during the first year, compared to a similarly aged nonstudent. These simulations suggest that the college experience does not contribute much to weight gain among young men and women. 
FIGURE 1

Annual Median Weight Gain Before, During, and After College

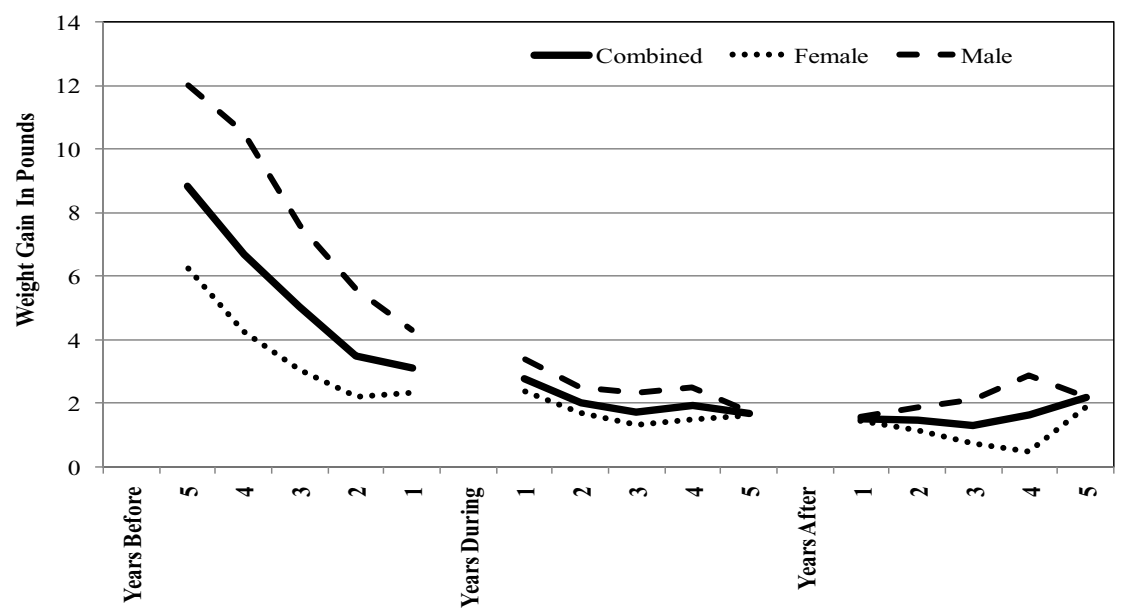

NOTES: Computations based on the NLSY97. The number of respondents varies by group and years. For example, the $N$ for the combined categories' six end points are: five years before 1,837, one year before 4,827, one year during 4,689, five years during 1,972, one year after 3,033, and five years after 599 .

\section{Longitudinal Analysis}

Because the NLSY97 is a panel survey that interviews the same respondents multiple times, it is possible to track longer term weight trends. Figure 1 shows the median weight change per year before, during, and after going to college among people who ever attended college. The figure's left-hand side, which tracks weight the five years before college, is calculated by extracting each respondent's weight $12,24,36,48$, and 60 months before the date college was started, when the typical NLSY97 respondent was 13 years old. Weight gain during this time period is expected because respondents are still physically developing. The amount of weight gained before a respondent begins higher education tapers off as college approaches. The typical respondent gained 8.8 pounds five years before college, but in the year before college, respondents gained only 3.1 pounds.

The middle part of Figure 1 shows that during the freshman year, college students gained on average (median) 2.76 pounds. Second-year students gained 2.0 pounds, while students in college more than two years gained slightly less than 2 pounds more per year. The right-hand side of the figure shows that respondents continued to gain weight in the five years after leaving 
college. $^{6}$ In the first four years after college, the typical respondent gained another 1.5 pounds per year. Median weight gain in the fifth year rose to 2.2 pounds, but this extra weight gain might be imprecisely measured since the sample size of 599 respondents is between a half and one-fifth smaller than any other data point on this graph.

Figure 1 reveals that college students do not face an elevated risk of obesity because they gain a large amount of weight during their freshman year. Instead, these college-educated individuals have moderate but steady weight gain throughout early adulthood. Anyone who continually gains 1.5 pounds annually will become obese over time, no matter their initial weight.

\section{Conclusion}

This research used a large nationally representative sample (NLSY97) to examine whether the "Freshman 15," the notion that college freshmen tend to gain a significant amount of weight, has any empirical support. Our results indicate that the "Freshman 15" is a media myth. While freshmen do gain weight, the observed average increase of 2.5 to 3.5 pounds falls far short of the ominous 15 pounds. Furthermore, among respondents ages 18 to 19, those who attended college gained only about half a pound more than nonattendees.

This study has implications for media reporting on weight issues among young adults. Repeated use of the phrase "the Freshman 15," even if it is being used just as a catchy alliterative figure of speech, may contribute to the misperception of being overweight, especially among young women. Several studies find that increased exposure to media conveying thinness as an ideal is associated with greater body dissatisfaction (Posavac, Posavac, and Posavac, 1998), increased negative emotions and self-objectification (Roberts and Gettman, 2004), and more eating disorder symptoms (Vaughn and Fouts, 2003). We recommend that media reports and campus communications reframe articles from concern about weight gain or overweight status to general healthy living or fitness tips and, when using the phrase "Freshman 15," articles should clearly state that this phenomenon has little scientific basis.

The results also suggest that the transition to college is not a critical point in the lifecourse in terms of weight gain, so directing government resources to programs designed to combat weight gain specifically among college freshmen is not a cost-effective approach to addressing the nation's high obesity rate. The problem is not that college students gain substantial weight during their freshman year, it is that individuals gain weight steadily during and after college. Since college is a time for learning, it is an opportune period to

\footnotetext{
${ }^{6}$ The month ending college was the last month the respondent attended any type or level of college. No distinction was made between full- and part-time studies or undergraduate and graduate studies.
} 
teach young adults about proper nutrition, healthy cooking, optimal portion sizes, and appropriate levels of physical activity. However, young adults not attending college also need such guidance so policymakers also need to think about how to best reach this group as well.

\section{REFERENCES}

American College Health Association. 2009. American College Health Association-National College Health Assessment II: Reference Group Data Report Fall 2008. Baltimore, MD: American College Health Association.

Anderson, D., J. Shapiro, and J. Lundgren. 2003. "The Freshman Year of College as a Critical Period for Weight Gain: An Initial Evaluation.” Eating Behaviors 4:363-67.

Baranowski, T., K. Cullen, K. Basen-Engquist, D. Wetter, S. Cummings, D. Martineau, A. Prokhorov, J. Chorley, B. Beech, and A. Hergenroeder. 1997. "Transitions Out of High School: Time of Increased Cancer Risk." Preventive Medicine 26(5):694-703.

Björntorp, P. 2001. "Do Stress Reactions Cause Abdominal Obesity and Comorbidities?" Obesity Reviews 2:73-86.

Bogin, B. 1999. Patterns of Human Growth. Cambridge: Cambridge University Press.

Brown, C. 2008. "The Information Trail of the 'Freshman 15'-A Systematic Review of a Health Myth Within the Research and Popular Literature." Health Information and Libraries Journal 25(1):1-12.

Butler, S., D. Black, C. Blue, and R. Gretebeck. 2004. "Change in Diet, Physical Activity, and Body Weight in Female College Freshmen." American Journal of Health Behavior 28(1):24-32.

Carskadon, M. 1990. "Patterns of Sleep and Sleepiness in Adolescents." Pediatrician 17:5-12.

Compas, B., B. Wagner, L. Slavin, and K. Vannatta. 1986. "A Prospective Study of Life Events, Social Support, and Psychological Symptomatology During the Transition from High School to College." American Journal of Community Psychology 14(3):241-57.

Dallman, M., N. Pecoraro, S. Akana, S. la Fleur, F. Gomez, H. Houshyar, M. Bell, S. Bhatnager, K. Laugero, and S. Manalo. 2003. "Chronic Stress and Obesity: A New View of Comfort Food." Proceedings of the National Academy of Science 100(20):11696-11701.

Delinsky, S., and G. Wilson. 2008. "Weight Gain, Dietary Restraint, and Disordered Eating in the Freshman Year of College." Eating Behaviors 9:82-90.

Demory-Luce, D., M. Morales, T. Nicklas, T. Baranowski, I. Zakeri, and G. Berenson. 2004. "Changes in Food Group Consumption Patterns from Childhood to Young Adulthood: The Bogalusa Heart Study.” Journal of the American Dietetic Association 104:1684-91.

Drapeau, V., D. Therrien, D. Richard, and A. Tremblay. 2003. "Is Visceral Obesity a Physiological Adaptation to Stress?” Panminerva Medica 45:189-95.

Drewnowski, A. 2004. "Obesity and the Food Environment: Dietary Energy Density and Diet Costs." American Journal of Preventive Medicine 27(3) Suppl:154-62.

Economos, C., L. Hildebrandt, and R. Hyatt. 2008. "College Freshman Stress and Weight Change: Differences by Gender." American Journal of Health Behavior 32(1):16-25.

Edmonds, M., K. Ferreira, N. Nikiforuk, A. Finnie, S. Leavey, A. Duncan, and J. Simpson. 2008. "Body Weight and Percent Body Fat Increase During the Transition from High School to University in Females." Journal of the American Dietetic Association 108: 1033-37. 
Gfroerer, J., J. Greenblatt, and D. Wright. 1997. "Substance Use in the U.S. College-Age Population: Differences According to Educational Status and Living Arrangement." American Journal of Public Health 87(1):62-65.

Gordon-Larsen, P., M. Nelson, and B. Popkin. 2004. "Longitudinal Physical Activity and Sedentary Behavior Trends Adolescence to Adulthood." American Journal of Preventive Medicine 27(4):277-83.

Graham, M., and A. Jones. 2002. "Freshman 15: Valid Theory or Harmful Myth?" Journal of American College Health 50(4):171-73.

Hajhosseini, L., T. Holmes, P. Mohamadi, V. Goudarzi, L. McProud, and C. Hollenbeck. 2006. "Changes in Body Weight, Body Composition and Resting Metabolic Rate (RMR) in First-Year University Freshmen Students." Journal of the American College of Nutrition 25(2):123-27.

Hasler, G., D. Buysse, R. Klaghofer, A. Gamma, V. Ajdacic, D. Eich, W. Rössler, and J. Angst. 2004. "The Association Between Short Sleep Duration and Obesity in Young Adults: A 13-Year Prospective Study." Sleep 27(4):661-66.

Hicks, R., C. Fernandez, and R. Pellegrini. 2001. "Striking Changes in the Sleep Satisfaction of University Students Over the Last Two Decades.” Perceptual and Motor Skills 93:660.

Hodge, C., L. Jackson, and L. Sullivan. 1993. “The 'Freshman 15': Facts and Fantasies About Weight Gain in College Women.” Psychology of Women Quarterly 17:119-26.

Hoffman, D., P. Policastro, V. Quick, and S. Lee. 2006. "Changes in Body Weight and Fat Mass of Men and Women in the First Year of College: A Study of the 'Freshman 15'." Journal of American College Health 55(1):41-45.

Holben, D., J. Hassell, and J. Holcomb. 1998. "College Freshmen Do Not Eat Within Food Pyramid Guidelines." Journal of the American Dietetic Association 98(9):A-51.

Holm-Denoma, J., T. Joiner, K. Vohs, and T. Heatherton. 2008. "The 'Freshman Fifteen' (The 'Freshman Five' Actually): Predictors and Possible Explanations." Health Psychology 27(1, Supp.):S3-S9.

Horovitz, B. 2007. "Something Else to Check Out at Library: Starbucks." USA Today September $27: 1 \mathrm{~B}$.

Hovell, M., C. Mewborn, Y. Randle, and S. Fowler-Johnson. 1985. "Risk of Excess Weight Gain in University Women: A Three-Year Community Controlled Analysis." Addictive Behaviors 10:15-28.

Jung, M., S. Bray, and K. Ginis. 2008. "Behavior Change and the Freshman 15: Tracking Physical Activity and Dietary Patterns in 1st-Year University Women." Journal of American College Health 56(5):523-30.

Kandiah, J., M. Yake, J. Jones, and M. Meyer. 2006. "Stress Influences Appetite and Comfort Food Preferences in College Women." Nutrition Research 26:118-23.

Klarenbach, S., R. Padwal, A. Chuck, and P. Jacobs. 2006. "Population-Based Analysis of Obesity and Workforce Participation." Obesity 14:920-27.

Larson, N., D. Neumark-Sztainer, P. Hannan, and M. Story. 2007. "Trends in Adolescent Fruit and Vegetable Consumption, 1999-2004." American Journal of Preventive Medicine 32(2):147-50.

Levitsky, D., C. Halbmaier, and G. Mrdjenovic. 2004. "The Freshman Weight Gain: A Model for the Study of the Obesity Epidemic." International Journal of Obesity 28:1435-42.

Lowe, M., R. Annunziato, J. Markowitz, E. Didie, D. Bellace, L. Riddell, C. Maille, S. McKinney, and E. Stice. 2006. "Multiple Types of Dieting Prospectively Predict Weight Gain During the Freshman Year of College." Appetite 47:83-90. 
Malinauskas, B., V. Aeby, R. Overton, T. Carpenter-Aeby, and K. Barber-Heidal. 2007. "A Survey of Energy Drink Consumption Patterns Among College Students." Nutrition Journal 35(6):6-35.

Megel, M., P. Hawkins, S. Sandstrom, M. Hoefler, and K. Willrett. 1994. "Health Promotion, Self-Esteem, and Weight Among Female College Freshmen." Health Values 18(4): $10-19$.

Morrow, M., K. Heesch, M. Dinger, H. Hull, A. Kneehans, and D. Fields. 2006. "Freshman 15: Fact or Fiction?" Obesity 14(8):1438-43.

National Center for Health Statistics. 2009. Health United States, 2008 with Chartbook. Hyattsville, MD: National Center for Health Statistics.

Nelson, M., R. Kocos, L. Lytle, and C. Perry. 2009. "Understanding the Perceived Determinants of Weight-Related Behaviors in Late Adolescence: A Qualitative Analysis Among College Youth." Journal of Nutrition Education and Behavior 41(4):287-92.

Nelson, M., D. Neumark-Sztainer, P. Hannan, J. Sirard, and M. Story. 2006. "Longitudinal and Secular Trends in Physical Activity and Sedentary Behavior During Adolescence." Pediatrics 118(6):e1627-34.

Nelson, M., M. Story, N. Larson, D. Neumark-Sztainer, and L. Lytle. 2008. "Emerging Adulthood and College-Aged Youth: An Overlooked Age for Weight-Related Behavior Change." Obesity 16:2205-11.

Pliner, P., and T. Saunders. 2008. "Vulnerability to Freshman Weight Gain as a Function of Dietary Restraint and Residence." Physiology \& Behavior 93:76-82.

Posavac, H., S. Posavac, and E. Posavac. 1998. "Exposure to Media Images of Female Attractiveness and Concern with Body Weight Among Young Women." Sex Roles 38(3/4): 187-92.

Pullman, A., R. Masters, L. Zalot, L. Carde, M. Saraiva, Y. Dam, J. Simpson, and A. Duncan. 2009. "Effect of the Transition from High School to University on Anthropometric and Lifestyle Variables in Males." Applied Physiology, Nutrition, and Metabolism 34:1-10.

Roberts, T., and J. Gettman. 2004. "Mere Exposure: Gender Differences in the Negative Effects of Priming a State of Self-Objectification." Sex Roles 51(1/2):17-27.

Rowland, M. 1990. "Self-Reported Weight and Height." American Journal of Clinical Nutrition 52:1125-33.

Sherry, B., M. Jefferds, and L. Grummer-Strawn. 2007. “Accuracy of Adolescent Self-Report of Height and Weight in Assessing Overweight Status. A Literature Review." Archives of Pediatrics \& Adolescent Medicine 161(12):1154-61.

Shields, D., K. Corrales, and E. Metallinos-Katsaras. 2004. "Gourmet Coffee Beverage Consumption Among College Women." Journal of the American Dietetic Association 104(4):650-53.

Spiegel, K., E. Tasali, P. Penev, and E. Van Cauter. 2004. "Sleep Curtailment in Healthy Young Men is Associated with Decreased Leptin Levels, Elevated Ghrelin Levels, and Increased Hunger and Appetite." Annals of Internal Medicine 141(11):846-50.

Thorpe, K. 2005. "The Rise in Health Care Spending and What to Do About It." Health Affairs 24(6):1436-45.

Tunceli, K., K. Li, and L. Williams. 2006. "Long-Term Effects of Obesity on Employment and Work Limitations Among U.S. Adults, 1986 to 1999.” Obesity 14:1637-46.

U.S. Department of Health and Human Services. 1996. Physical Activity and Health: A Report of the Surgeon General. Washington, DC: Centers for Disease Control \& Prevention, National Center for Chronic Disease Prevention and Health Promotion. 
Vaughn, K., and G. Fouts. 2003. "Changes in Television and Magazine Exposure and Eating Disorder Symptomatology.” Sex Roles 49(7/8):313-20.

Wansink, B., M. Cheney, and N. Chan. 2003. "Exploring Comfort Food Preferences Across Age and Gender." Physiology \& Behavior 79:739-47.

Watkins, T. 1989. “Fight the Freshman 15.” Seventeen 48:162.

Wechsler, H., and T. Nelson. 2008. "What We Have Learned from the Harvard School of Public Health College Alcohol Study: Focusing Attention on College Student Alcohol Consumption and the Environmental Conditions that Promote It." Journal of Studies on Alcohol and Drugs 69:481-90.

Wee, C., R. Phillips, A. Legedza, R. Davis, J. Soukup, G. Colditz, and M. Hamel. 2005. "Health Care Expenditures Associated with Overweight and Obesity Among U.S. Adults: Importance of Age and Race." American Journal of Public Health 95(1):159-65.

Zagorsky, J., and P. Smith. 2009. "Does the U.S. Food Stamp Program Contribute to Adult Weight Gain?” Economics and Human Biology 7:246-58. 